\title{
Ultrasound evaluation of female reproductive system in free ranging Giant Anteater (Myrmecophaga tridactyla): case report
}

[Avaliação ultrassonográfica do sistema reprodutor feminino em tamanduá-bandeira de vida livre (Myrmecophaga tridactyla): relato de caso]

\author{
M.C. Maronezi ${ }^{1}$, G.G. Lemos $^{1}$, F.H. Lima ${ }^{1}$, L.M. Izique ${ }^{1}$, M. De Santi ${ }^{1}$, C. Couto ${ }^{1}$, T.M. Pereira ${ }^{2}$, \\ R.A.R. Uscategui ${ }^{3}$, B.W. Minto ${ }^{1}$, K. Werther ${ }^{1}$, M.A.R. Feliciano ${ }^{1,2 *}$ \\ ${ }^{1}$ Faculdade de Ciências Agrárias e Veterinárias - UNESP/Jaboticabal, SP \\ ${ }^{2}$ Universidade Federal de Santa Maria - UFSM-/Santa Maria, RS \\ ${ }^{3}$ Universidade Federal dos Vales do Jequitinhonha e Mucuri - UFVJM/Unaí, MG
}

\begin{abstract}
An adult, female, $31 \mathrm{~kg}$ body weight, free range Myrmecophaga tridactyla was referred for medical consultation due to apathy, dehydration, intense flatulence and fetid stools. The animal was submitted to chemical restraint and physical examination, blood count, fecal analysis, and vaginal cytology and abdominal ultrasonography were performed. Good nutritional status and clinical variables within the normal range were observed at physical examination. At vaginal cytology leukocytes, spermatozoa and a large proportion of cornified cells (superficial) were observed, indicating estrus and recent copula. At ultrasound examination it was possible to locate, identify, evaluate and measure the ovaries and the uterine structures, cervix, body, lumen, myometrium and endometrium, a fact never reported in the literature for this species. These data can be used as reference for clinical evaluation of the reproductive tract in Myrmecophaga tridactyla females considered vulnerable species, for the diagnosis of reproductive pathologies, biotechnologies application or estrous cycle evaluation.
\end{abstract}

Keywords: ovary, uterus, estrous cycle, Xenarthra

\section{RESUMO}

Uma fêmea, com $31 \mathrm{~kg}$ de peso corporal, de Myrmecophaga tridactyla, de vida livre, foi apresentada para consulta médica em razão de apatia, desidratação, flatulência intensa e fezes fétidas. $O$ animal foi submetido à contenção química e foram realizados exame físico, hemograma, análise fecal, citologia vaginal e ultrassonografia abdominal. Ao exame físico, foi determinado bom estado nutricional $e$ variáveis clínicas dentro da faixa de normalidade. Na citologia vaginal, foram observados leucócitos, espermatozoides e uma grande proporção de células cornificadas (superficiais), indicando estro e cópula recente. No exame ultrassonográfico, foi possível localizar, identificar, avaliar e mensurar os ovários e as estruturas uterinas, o colo do útero, o corpo do útero, o lúmen, o miométrio e o endométrio, fato nunca relatado na literatura para essa espécie. Esses dados podem ser utilizados como referência para avaliação clínica do trato reprodutivo de fêmeas de Myrmecophaga tridactyla considerada espécie vulnerável, para o diagnóstico de patologias reprodutivas, aplicação de biotecnologias ou avaliação do ciclo estral.

Palavras-chave: ovário, útero, ciclo estral, Xenarthra

Recebido em 30 de setembro de 2019

Aceito em 27 de novembro de 2019

*Autor para correspondência (corresponding author)

E-mail: marcusfeliano@yahoo.com.br 


\section{INTRODUCTION}

The Giant Anteater (Myrmecophaga tridactyla) is an insectivorous mammal native to Central and South America, belonging to the Myrmecophagid family, Pilosa order and Xenarthra superorder, being the largest representative of this family. This species is considered vulnerable by the International Union for Conservation of Nature (Jerez and Halo, 2003). The knowledge of the reproductive biology of Myrmecophaga tridactyla is limited, only its estrous cycle has been described by Rezende (2013). These animals were defined reproductively as non-seasonal polyestrous, with an estrous cycle that lasts 51 days, the follicular phase of approximately 15 days and anestrus of about 21 days (Luna et al., 2014).

The reproductive system of Myrmecophaga tridactyla females shows vaginal vestibule, vagina and uterus and the topographic anatomy of the uterine structure is similar to the primates, with simple and piriform conformation, located in the pelvic cavity, between rectum and urinary bladder, attached to lateral wall by uterus ligaments, which accommodates the ovaries laterally and dorsally to kidneys (Silva et al., 2010; Rossi et al., 2011).

The ultrasound exam demonstrated applicability for identification and evaluation of the reproductive system in wildlife animals, with a relevant role in the preservation of these species (Feliciano et al., 2014). This image technique contributes to the establishment of more effective morphophysiological evaluation, clinical diagnoses and therapeutic measures, allows noninvasively, quickly, accurate and detailed tissue evaluation on any condition in free-living or captivity animals (Nepomuceno et al., 2013). Reports of Myrmecophaga tridactyla female reproductive system ultrasonographic anatomy were not found and, in this context, this report aims to describe the ultrasonographic findings of the uterine and ovarian structures in his species, trying to provide ultrasound parameters for its clinical evaluation.

\section{CASUISTRY}

An adult, female, $31 \mathrm{~kg}$ body weight, free-range Myrmecophaga tridactyla was rescued by the fire department of Taquaritinga, SP, in a city road, and then referred to the "Governador Laudo Natel" Teaching Veterinary Hospital, UNESP, Jaboticabal -SP. The animal showed signs of apathy, dehydration, intense flatulence and fetid stools.

For clinical evaluation, the animal was chemically restrained with intramuscular ketamine $11 \mathrm{mg} / \mathrm{kg}$ and midazolam $0.2 \mathrm{mg} / \mathrm{kg}$ association. Once immobilized, the physical examination was performed and fecal, blood samples, vaginal smear were collected for blood count, fecal exam and vaginal cytology. To perform the vaginal smear, the vulva was cleaned with saline and chlorhexidine $2 \%$, subsequently a sterile swab was introduced into the vagina, smeared on a microscope slide and stained with panoptic solution.

After sample collection, the Myrmecophaga tridactyla underwent abdominal ultrasound evaluation in supine position, after hair removal and conductive gel application. The exam was done by an experiment veterinary radiologist, using ACUSON S2000 ultrasound (Siemens, Munich, Germany) and a multifrequency linear transducer (4.5 - 9.0 MHz). The longitudinal and transverse sections of uterine and ovarian tissues were evaluated for echogenicity, echotexture, location, contours, shape and biometry. During the entire period of chemical restraint, cardiac and respiratory rate and rectal temperature were monitored.

Upon physical exam the Myrmecophaga tridactyla presented good nutritional status, clinical signs compatible with 5\% dehydration, mild caudal abdomen pain, mucous vaginal discharge, but with physiological parameters within what is considered normal, and blood count without any alterations indicating disease. The patient was hydrated and due to reproductive signs, vaginal cytology and reproductive ultrasound examinations were performed, as previously described.

During reproductive inspection, the vulva was found swollen with reddish mucosa. Upon cytological exam of vaginal smear some leukocytes, spermatozoa and a large proportion of cornified (superficial) cells, characterized as disintegrated, little definite and without visible vacuolated nuclei (Figure. 1) were found. With these results, presumptive diagnosis changed 
from uterine infection to estrus, and a recent copula. In order to make the definitive dismissal of the diagnosis of uterine infection, ultrasound was performed.

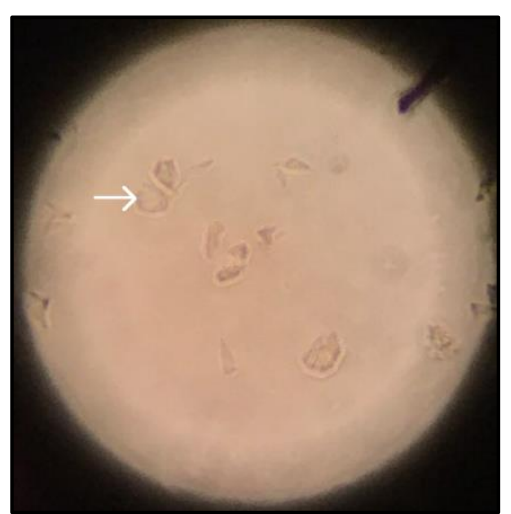

Figure 1. Image of the vaginal cytology of Myrmecophaga tridactyla. Note the superficial enucleated and scaly cells (arrow).

Through ultrasound evaluation, the uterus was located in the medial portion of the abdomen, in anterior-posterior position, dorsal to the urinary bladder and presenting a simple pyriform shape. The uterine body was cranial and dorsal to the urinary bladder, with a dorsoventral diameter of $2.1 \mathrm{~cm}$. The uterus was hypoechoic in relation to adjacent tissues, with homogeneous echotexture, regular contours and visible uterine lumen as a central and brilliant echogenic area. Additionally, it was possible to delimit the portions of the uterine wall: myometrium and endometrium, both with regular contours, the myometrium being more echogenic than the endometrium.

The cervix was located caudal to the uterine body and showed an elongated shape, with dorsoventral diameter of $1.8 \mathrm{~cm}$, hypoechoic in relation to the adjacent tissues, isoechoic to the uterine body, with heterogeneous echotexture and central echogenic area corresponding to the lumen that measured $0.28 \mathrm{~cm}$ (Figure. 2).

For ultrasound location of the ovaries, first the kidneys were identified and a scan was performed around them, the ovaries were visualized dorsally to the kidneys, featuring an elongated and flattened shape, measuring $1.98 \mathrm{~cm}$ $\mathrm{x} 0.98 \mathrm{~cm}$ and $1.9 \times 0.87 \mathrm{~cm}$ for the left and right ovary, respectively. The echogenicity of these structures was isoechoic in relation to the renal cortex with presence of hyperechoic central line well evident and homogeneous echotexture (Figure. 3).

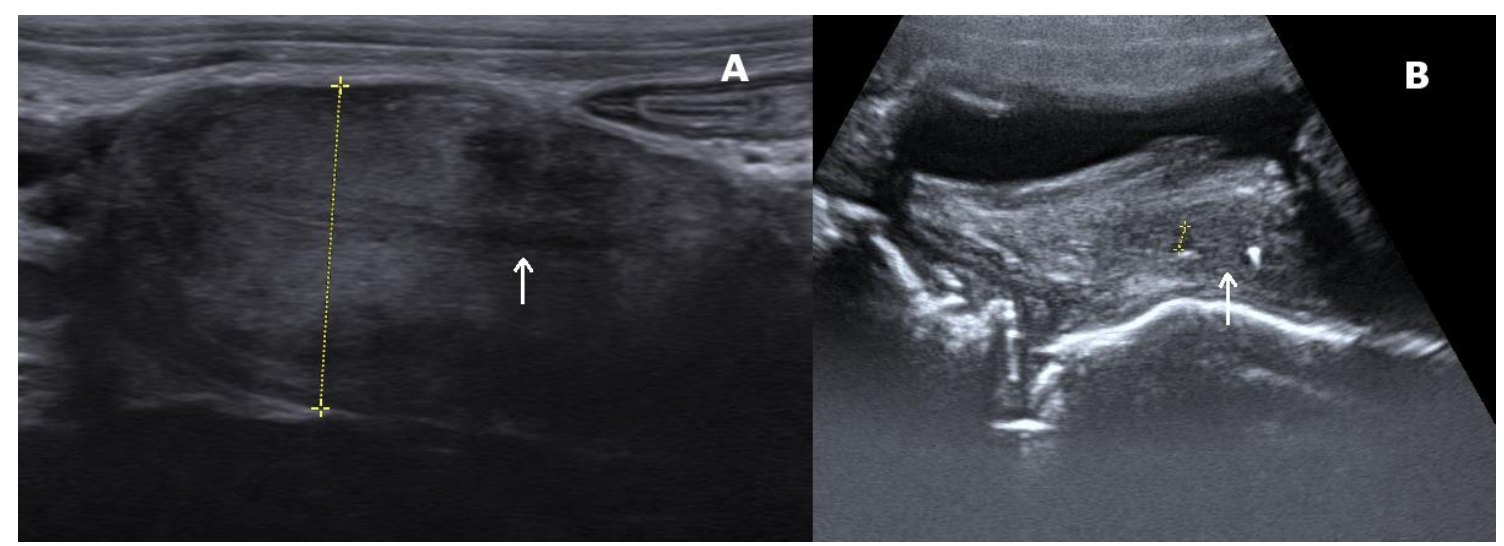

Figure 2. Ultrasound image of uterus and uterine lumen (arrow) of adult Myrmecophaga tridactyla (A); Bottom of the uterus to the cervix (arrow) (B). 


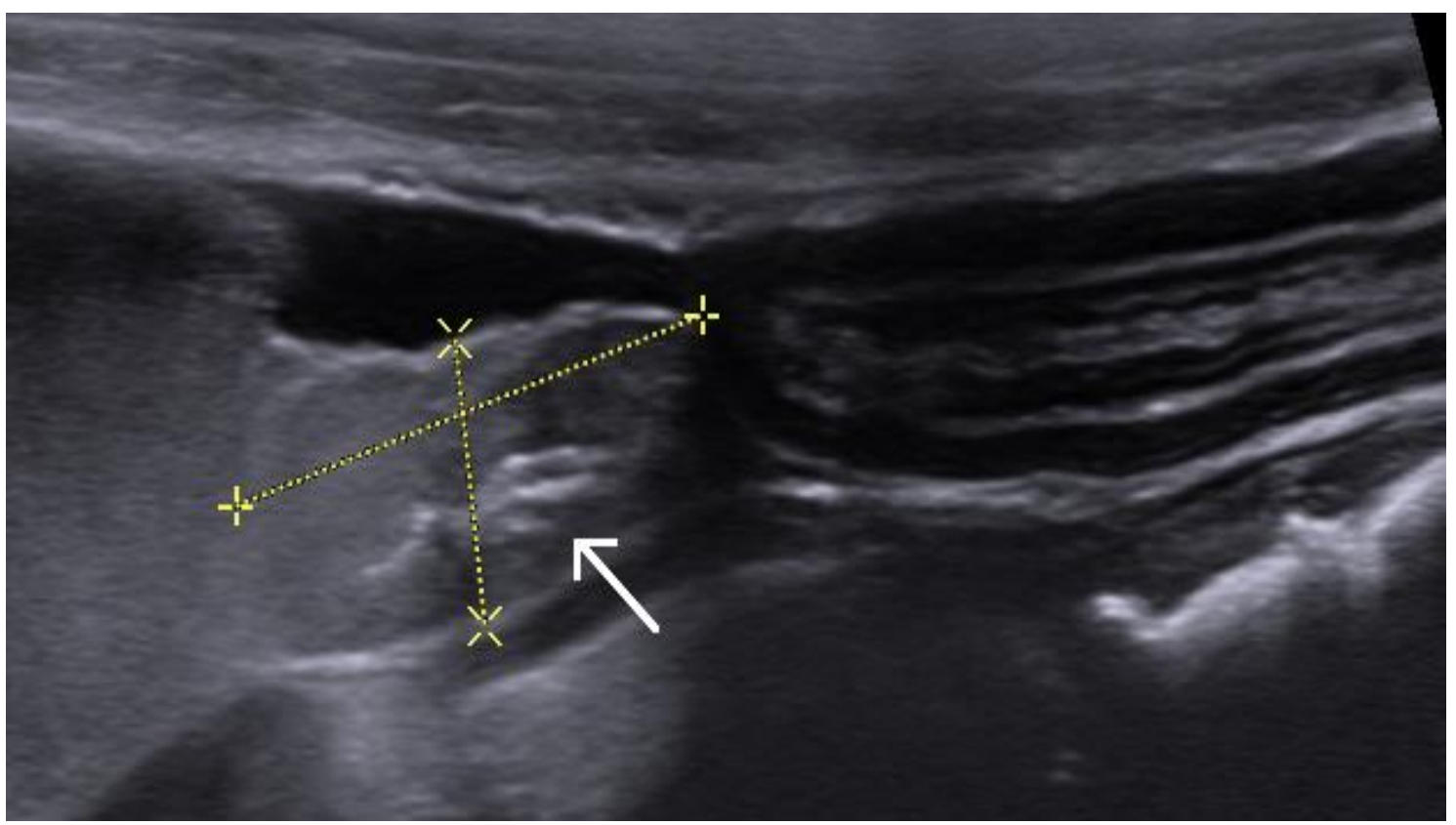

Figure 3. Ultrasound image of the right ovary measurement of Myrmecophaga tridactyla, with presence of central hyperechoic area (arrow) in adult anteater.

\section{DISCUSSION}

Lopes et al. (2015) performed abdominal ultrasonography on three female Myrmecophaga tridactyla to evaluate the abdominal structures, reported difficulties for uterus and ovary localization, and concluded that it is not possible to visualize these structures. However, in this report reproductive system ultrasound was performed without any difficulties, promoting visualization and complete evaluation of the uterine and ovarian structures, not yet described in the literature for the species. The use of 9.0 $\mathrm{MHz}$ transducer and the state of estrus probably benefited the visibility of the reproductive structures, once Lopes et al. (2015), report the use of equipment configurations with greater penetration of the ultrasound beam (below $3.5 \mathrm{MHz}$ ) and report nothing about the state of the female estrous cycle. With these precepts, the use of high frequency transducers may be indicated for reproductive exam of Myrmecophaga tridactyla.

Upon vaginal cytology, the vaginal epithelium pattern observed was composed principally by cornified (superficial) cells, and this finding is similar to the related in the estrus phase of Tamandua tetradactyla (Soboll, 2008) a phylogenetically close species of Myrmecophaga tridactyla. In addition, spermatozoa were found on the cytology slide, confirming the recent copula, a fact that states the diagnosis of estrus.

Uterine ultrasound characteristics of Myrmecophaga tridactyla were similar to nonhuman primates, in topography, shape, echogenicity and echotexture (Coutinho et al., 2013), having an anatomic description very similar to that done in Aotus azarae (Monteiro et al., 2009). The endometrium and myometrium were evident, with regular contours and surfaces, free of abnormalities, and with a diameter of 2.1 $\mathrm{cm}$, these findings corroborate the ex-vivo anatomical description made for the species regarding to size $(2$ to $3 \mathrm{~cm}$ ) and uterine layers (Rossi et al., 2011).

There are few reports about ultrasound identification of uterine lumen in wildlife animals; its known that uterine lumen in bitches is not visible in normal situations, however, during estrus it can be seen as a central and brilliant echogenic area, which represents a small amount of intraluminal mucus (Davidson and Baker, 2009). Such structure was detected easily and with characteristics similar to the canine estrus. 
The ovaries were visible dorsally and adjacent to the kidney, corroborating the ex-vivo description by Silva et al. (2010) in Myrmecophaga tridactyla, who described the position dorsally to the kidneys and medially to the rectum, presenting a long uterine ligament, different from females of non-human primates that presented a short ovary ligament (Monteiro et al., 2009; Coutinho et al., 2013). Upon ultrasound evaluation the ovaries presented a hyperechoic central line, corresponding to medullary-cortical separation. According to Rossi et al. (2011) the left ovary is slightly larger than the right ovary, with a length ranging from 0.5 to $2.3 \mathrm{~cm}$ and a width of 0.4 to $1.0 \mathrm{~cm}$, corroborating the measures described in this report.

Associating ultrasound findings with vaginal cytological description it was suggested that the Myrmecophaga tridactyla was in estrous phase, corroborating with the literature that report difficulty to locate the uterus, unless there is increase due to hormonal influence, during the estrous cycle. Since, during estrus, the uterine walls become thicker, the differentiation between the endometrium and myometrium was possible due to the estrogen influence (Nepomuceno et $a l ., 2013)$. In addition, in primates the uterus undergoes physiological changes, which are more evident in the estrus period, where the uterus is enlarged (Kuederling and Heistermann, 1997).

\section{CONCLUSION}

Ultrasound evaluation of female reproductive system of Myrmecophaga tridactyla is a feasible exam, permitting structural evaluation without difficulty, where it is possible to locate, identify, evaluate and measure the ovaries and the uterine structures, cervix, body, lumen, myometrium and endometrium, a fact never reported in the literature for this species. This data can be used as reference for clinical evaluation of the reproductive tract in Myrmecophaga tridactyla females considered vulnerable species, for the diagnosis of reproductive pathologies, biotechnologies application or estrous cycle evaluation.

\section{ACKNOWLEDGMENTS}

The authors would like to thank the State of Sao Paulo Research Foundation (FAPESP protocol numbers: 2017/14957-6 and 2019/15282-8) and National Council for Scientific and Technological Development by research grant and productivity scholarship award (processes 430023/2018-9 and 309199/2017-4). The authors also thank Jair Matos and Siemens Healthineers for technical assistance.

\section{REFERENCES}

COUTINHO, L.N.; BRITO, M.B.S.; MONTEIRO, F.O.B. et al. Analysis of follicular events in owl monkeys (Aotus azarai infulatus) using B-mode and Doppler ultrasound. Theriogenology, v.80, p.99-103, 2013.

DAVIDSON, A.P.; BAKER, T.W. Reproductive ultrasound of the bitch and queen. Top. Companion Anim. Med., v.24, p.55-63, 2009.

FELICIANO, M.A.R.; BARROS, F.F.P.C.; COUTINHO, L.N. et al. Conventional and Doppler Abdominal Ultrasonography in Pacas (Cuniculus paca - Linnaeus, 1766). Acta Scientiae Veterinariae, v.42, p.1235-1241, 2014.

JEREZ, V.S.; HALLO, Y.M. El oso hormiguero, myrmecophaga tridactyla: crescimiento e independizacion de uma cria. J. Neotrop. Mamm., v.10, p.323-330, 2013.

KUEDERLING, I.; HEISTERMANN, M. Ultrasonographic and hormonal monitoring of pregnancy in the saddle back tamarin, Saguinus fuscicollis. J. Med. Primatol., v.26, p.299-306, 1997.

LOPES, E.R.; MORGADO, T.O.; MEIRELES, Y.S. et al. Ultrasound in anteaters (Myrmecophaga tridactyla Linnaeus, 1758) in captivity. Pesqui. Vet. Bras., v.35, p.919-924, 2015.

LUNA, H.S.; HOSSOTANI, C.M.S.; MOREIRA, F.M.A. Efforts for the conservation of the Myrmecophaga tridactyla species, linnaeus, 1758: technologies applied to reproduction. Rev. Bras. Reprod. Anim., v.38, p.10-14, 2014.

MONTEIRO, F.O.B.; COUTINHO, L.N.; POMPEU, E.S.S. et al. Ovarian and uterine ultrasonography in Aotus azarai infulatus. Int. J. Primatol., v.30, p.327336, 2009. 
NEPOMUCENO, A.C.; GARCIA, D.A.A.; BARROS, F.F.P.C. Ultrassonografia do sistema reprodutor feminino de pequenos animais. In: FELICIANO, M.A.R.; OLIVEIRA, M.E.F.; VICENTE, W.R.R. (Eds.). Ultrassonografia na reprodução. São Paulo: MedVet, 2013. p.41-67.

REZENDE, L.C.; GALDOS-RIVEROS, A.C.; MIGLINO, M.A.; FERREIRA, J.R. Biology of reproduction in the sloth and anteater: a review. Rev. Bras. Reprod. Anim., v.37, p.354-359, 2013.

ROSSI, L.F.; LUACES, J.P.; ALDANA-MARCOS, H.J. et al. Female reproductive tract of the lesser anteater (Tamandua tetradactyla, Myrmecophagidae, Xenarthra): anatomy and histology. J. Morphol., v.272, p.1307-1313, 2011
SILVA, M.P.; REZENDE, L.C.; ALCÂNTARA, D.; MIGLINO, M.A. Análise comparativa da morfologia uterina do bicho preguiça, tamanduá e tatu (Xenarthras). Enciclopédia Biosfera, v.6, p.1-7, 2010.

SOBOLL, D.S. Avaliação do ciclo reprodutivo em três fêmeas adultas de tamanduá-mirim (Tamandua tetradactyla) por meio da citologia vaginal. 2008. 33f. Monografia (Especialização em Clínica Médica e Cirúrgica de Animais Selvagens e Exótico) Universidade Castelo Branco, São Paulo, SP. 